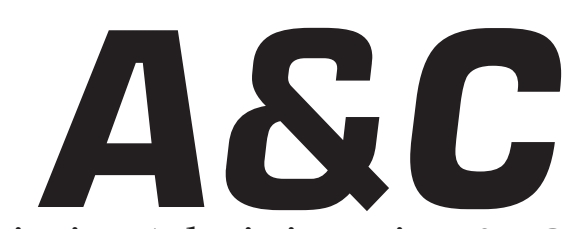

Revista de Direito Administrativo \& Constitucional

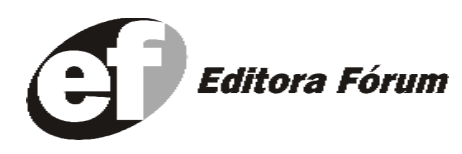

A\&C R. de Dir. Administrativo e Constitucional, Belo Horizonte, ano 4, n.15, p.1-256, jan./mar. 2004 
A\&C REVISTA DE DIREITO ADMINISTRATIVO E CONSTITUCIONAL

\section{IPDA}

Instituto Paranaense

de Direito Administrativo

Direção Geral

Romeu Felipe Bacellar Filho

Direção Editorial

Paulo Roberto Ferreira Motta

Direção Executiva

Emerson Gabardo

Conselho de Redação

Edgar Chiuratto Guimarães

Adriana da Costa Ricardo Schier

Célio Heitor Guimarães

Conselho Editorial

\begin{tabular}{|c|c|}
\hline Adilson Abreu Dallari & Manoel de Oliveira Franco Sobrinho \\
\hline Alice Gonzáles Borges & (in memoriam) \\
\hline Carlos Ari Sundfeld & Marçal Justen Filho \\
\hline Carlos Ayres Britto & Marcelo Figueiredo \\
\hline Carlos Delpiazzo & Márcio Cammarosano \\
\hline Lúcia Antunes Rocha & Maria Cristina Cesar de Oliveira \\
\hline de Mello & Nelson Figueiredo \\
\hline èmerson Merlin Clève & Odilon Borges Junior \\
\hline Enrique Silva Cimma & Pascual Caiella \\
\hline Eros Roberto Grau & Paulo Eduardo Garrido Modesto \\
\hline Fabrício Motta & Paulo Henrique Blasi \\
\hline ilhermo Andrés Muñoz & Paulo Ricardo Schier \\
\hline Jorge Luís Salomoni & Pedro Paulo de Almeida Dutra \\
\hline José Carlos Abraão & Regina Maria Macedo Nery Ferrari \\
\hline uardo Martins Cardoso & Rogério Gesta Leal \\
\hline José Luís Said & Rolando Pantoja Bauzá \\
\hline José Mario Serrate Paz & Sérgio Ferraz \\
\hline Pablo Cajarville Peruffo & Valmir Pontes Filho \\
\hline Juarez Freitas & Yara Stropa \\
\hline Julio Rodolfo Comadira & Weida Zancanne \\
\hline
\end{tabular}

Lúcia Valle Figueiredo

Luís Enrique Chase Plate

Os conceitos emitidos em trabalhos assinados são de responsabilidade de seus autores, que gozam de inteira

liberdade de opinião. e-mail para remessa de artigos, pareceres e contribuições: e.gab.@uol.com.br

ou conselho@editoraforum.com.br Endereço para envio de contribuições: Editora Fórum

Revista A\&C, Av. Afonso Pena, 2770, 15\%16 a andar, Funcionários, CEP 30130-007 - Belo Horizonte - MG

A\&C Revista de Direito Administrativo e Constitucional. Ano 3, n. 11, jan./mar. 2003. Belo Horizonte: Fórum, 2003.

Trimestral

ano 1, n.1, 1999 até ano 2, n.10, 2002 publicada pela Editora Juruá em Curitiba

ISSN: 1516-3210

1. Direito Administrativo. 2. Direito Constitucional. I. Fórum.

CDD: 342 CDU: 33.342
Editor responsável: Luis Cláudio Rodrigues Ferreira Projeto gráfico: Luis Alberto Pimenta

Diagramação: Luis Alberto Pimenta

Revisora: Olga M. A. Sousa

Pesquisa jurídica: Fátima Ribeiro - OAB/MG 74868 Bibliotecária: Nilcéia Lage de Medeiros -

CRB 1545/MG - 6 a região

(c) Editora Fórum Ltda., 2003.

Proibida a reprodução total ou parcial desta obra, por qualquer meio eletrônico, inclusive por processos xerográficos, sem autorização expressa do editor.

Distribuída em todo o território nacional

Assinaturas e comercialização:

Editora Fórum, Av. Afonso Pena, 2770, 15-16 andar, Funcionários, CEP 30130-007 - Belo Horizonte - MG Tel.: (31) 2121-4900 - 0800 704-3737

e-mail: editoraforum@editoraforum.com.br site: www.editoraforum.com.br 


\title{
Os Pressupostos Epistemológicos e Filosóficos da Gestão de Políticas Públicas no Estado Democrático de Direito: uma Perspectiva Habermasiana ${ }^{1}$
}

\section{Rogério Gesta Leal}

Doutor em Direito, Professor Universitário e Desembargador do Tribunal de Justiça do Estado do Rio Grande do Sul. Coordenador do Programa de Mestrado em Direito da Universidade de Santa Cruz do Sul

\begin{abstract}
Sumário: 1 Notas introdutórias - 2 Considerações críticas sobre o evolver do Estado administrador brasileiro - 3 Estado e Sociedade Democrática de Direito: uma análise habermasiana - 4 Governabilidade democrática e participação política: possibilidades - 4.1 Participação social e complexidade administrativa - 4.2 Participação pública dos sujeitos sociais e representação institucional - 5 Pressupostos fundacionais da Administração Comunicativa - 6 Considerações finais - Bibliografia
\end{abstract}

Resumo: Pretende o presente ensaio: (a) identificar quais os pressupostos teóricos (filosóficos e políticos) que informam a vigente e tradicional concepção de gestão de políticas públicas no âmbito da Teoria do Estado Moderno de Direito; (b) demarcar os limites de esgotamento deste modelo; (c) avaliar como o contributo filosófico de Jürgen Habermas à Teoria da Democracia Procedimental pode auxiliar na constituição de um novo paradigma jurídico e político à gestão pública contemporânea dos interesses e demandas sociais.

Palavras-chave: Gestão pública, poder político, participação social

\section{Notas introdutórias}

O tema central que pretendemos desenvolver neste ensaio é o que diz respeito a sabermos se é possível constituirmos pressupostos filosóficos e políticos fundadores de um estatuto teórico e instrumental à Administração Pública, aqui entendida como gestão pública compartida, que conta com a efetiva participação popular em todos os seus âmbitos.

Partiremos, para tanto, das contribuições filosófico-políticas de Jürgen Habermas, e da premissa - a ser fundada no esteio das razões que seguem — de que a administração pública de demandas sociais precisa ser, primeiro, compreendida a partir de uma nova perspectiva teórico-social, viabilizadora

\footnotetext{
1 Este trabalho é o resultado parcial de uma pesquisa financiada pela Universidade de Santa Cruz do Sul, desenvolvido ao longo do ano de 2002
} 
de uma racionalidade civilizatória e complexa de inclusão e compromisso comunitário; segundo, precisa ser vista como espaço permanente de controle e participação social no âmbito da gestão dos interesses públicos. Para tanto, o Direito tem uma função exponencial, notadamente a partir de sua dimensão constitucional, que, no caso brasileiro, institui uma nova era política no país, fundada nos direitos humanos e fundamentais, e numa concepção de cidadania ativa - enquanto sujeito de direitos a serem implementados e garantidos.

\section{Considerações críticas sobre o evolver do Estado administrador brasileiro}

De alguma maneira é possível afirmarmos que a história do cotidiano brasileiro, bloqueada pelo capital a pelo poder, fez da vida do homem simples das ruas continentais deste país o refúgio para o desencanto de um futuro improvável. Os grandes embates pela redenção do gênero humano de suas limitações e misérias estão sendo readaptados a esse novo território da vida e do viver. A sociedade está sendo reinventada e conseqüentemente as perspectivas de sua compreensão também estão passando por um processo de reinvenção. É nesse âmbito que ganha relevância a mediação do conhecimento do dia-a-dia na construção das relações sociais. ${ }^{2}$ Em tal cenário, o novo herói da vida é o homem comum, imerso no cotidiano, pois, no pequeno mundo de todos os dias está também o tempo e o lugar da eficácia das vontades individuais, daquilo que faz a força da sociedade civil, dos movimentos sociais.

Paradoxalmente, no evolver também histórico das comunidades, a quantidade de relações que constituem o seu funcionamento, da economia e da política, aumenta de maneira exponencial, de sorte que o leque de variáveis ligadas a um objeto ou fenômeno é bem mais amplo no período atual, tendo se complexificado neste evolver.

Assim, podemos dizer, com Milton Santos que, quanto mais os lugares se mundializam, mais se tornam singulares e específicos, isto é, únicos. Isto se deve à especialização desenfreada dos elementos do espaço - homens, firmas, instituições, meio ambiente - à dissociação sempre crescente dos processos e subprocessos necessários a uma maior acumulação de capital, à multiplicação das ações que fazem do espaço um campo de

\footnotetext{
2 Neste sentido ver o texto de MARTINS, José de Souza. O Senso Comum e a Vida Cotidiana. Tempo Social - Revista Sociologia, 1998, p. 34.
}

A \& C R. de Dir. Administrativo e Constitucional, Belo Horizonte, ano 4, n. 15, p. 149-179, jan./mar. 2004 
forças multidirecionais e multicomplexas, onde cada lugar é extremamente distinto do outro, mas também claramente ligado a todos os demais por um nexo único, dado pelas forças motrizes do modo de acumulação hegemonicamente universal. ${ }^{3}$

O cotidiano e a história da administração pública no Brasil vem marcada por todos estes fatores e cenários, a uma, porque sempre estiveram associadas com as iniciativas institucionais do Estado em termos de políticas públicas e atos administrativos (tanto legislativas, executivas como judiciais), a duas, porque contaram, em sua maior extensão, com uma sociedade civil adormecida em práticas republicanas de reivindicação e participação políticas.

Veja-se que, desde o século XV, Portugal, transpondo o ciclo da monarquia agrária para transformar-se num país de caráter mercantil, foi logo atingido por um estágio de congelamento em termos de avanços e conquistas em níveis sociais, haja vista o caráter estacionário e mesmo parasitário da nobreza como gestora das atividades públicas em termos de planejamento e desenvolvimento comunitário. ${ }^{4}$

Assim, quando Portugal, na peripécia do processo das descobertas, depara-se com a Terra de Santa Cruz, a Colônia, que passará a ser, em pouco tempo, a jóia mais preciosa do Império, passa a sofrer os influxos daquele condicionamento cultural, ao mesmo tempo em que as populações que para aqui vinham compostas de degredados e de elementos da pequena nobreza teriam de se adaptar a novos tipos de atividades econômicas. Por isso mesmo, a rarefação do poder político, nos primeiros séculos, dá margem a um processo de fortalecimento do poder privado, conforme as ponderações de Venâncio Filho. ${ }^{5}$

\section{É Plínio Barreto que vai dizer que:}

Há 100 anos, quando se emancipou definitivamente da soberania portuguesa, era o Brasil uma terra sem cultura jurídica. Não a tinha de espécie alguma, a não ser, em grau secundário, a do solo. Jaziam os espíritos impotentes na sua robustez meio rude da alforria das crendices e das utopias, à espera de charrua e sementes. O direito, como as demais ciências e, até, como as artes elevadas, não interessava ao analfabetismo integral da massa. Sem escolas que o ensinassem, sem imprensa que o divulgasse, sem agremiações que o estudassem, estava o conhecimento

\footnotetext{
SANTOS, Milton. Metamorfoses do Espaço Habitável. São Paulo: HUCITEC, 1997, p. 34.

4 Ver neste sentido o texto de PRADO JR., Caio. História do Desenvolvimento Econômico do Brasil. Rio de Janeiro: Círculo do Livro, 1996, p. 26 et seq.

5 VENÂNCIO FILHO, Alberto. Das Arcadas ao Bacharelismo. São Paulo: Perspectiva, 1982, p. 38.
} 
dos seus princípios concentrado apenas no punhado de homens abastados que puderam ir a Portugal apanhá-la no curso acanhado e rude que se processava na Universidade de Coimbra. ${ }^{6}$

Ora, tudo isto contribui para que os governantes desenvolvessem sentimentos de proprietários das instituições e do poder político que representavam, realizando a seu bel prazer o que bem entendiam em termos de administração, notadamente mais para atender expectativas corporativas do que comunitárias.

Desde a fundação das capitanias hereditárias, em meados do século XVI no Brasil, as figuras feudais dos capitães-mor figuravam como os fiéis escudeiros da Corte, cuja preocupação era tão-somente a de extrair do território do país os maiores dividendos possíveis, tudo consoante as disposições tanto das Cartas de Doação e dos Forais, bem como das Ordenações do Reino, notadamente o Código Manuelino. ${ }^{7}$

Tais instrumentos normativos não estavam preocupados em prever formas e mecanismos de ordenação à ocupação do solo, tampouco estabelecia requisitos para a exploração econômica, já que este era um tema até mesmo na Europa pouco observado.

Estes aspectos demonstram bem a matriz privativista de formatação do pensamento e da ação administrativa no território nacional, descurando completamente da natureza comunitária do processo de exploração dos recursos naturais e de formatação do espaço urbano e rural dos núcleos habitacionais.

Mesmo após a parcial descentralização administrativa ocorrida em 1549, com a implantação no país do Governo Geral, com a estipulação de regras às atividades administrativas dos governadores e de seus auxiliares, reduzindo o poder absoluto dos novos senhores feudais (donatários das capitanias), o certo é que, em face da enorme extensão territorial que sempre marcou o Brasil, inexistia um programa de ação integrado e orgânico para o país, mas somente programas isolados de administração territorial principalmente nos grandes centros habitados —, sem reverter isto para um conjunto ordenado e homogêneo de políticas voltadas a modelos de desenvolvimento integrado. ${ }^{8}$

\footnotetext{
${ }^{6}$ BARRETO, Plínio. A Cultura Jurídica no Brasil (1822/1922). Rio de Janeiro: Imprensa Nacional, 1938, p. 13.

7 Ver o texto de LYRA, Augusto Tavares. Organização Política e Administrativa do Brasil. Rio de Janeiro: Olympio, 1954, p. 22.

8 Conforme IGLÉSIAS, Francisco. Trajetória Política do Brasil. São Paulo: Cia das Letras, 1993, p. 53 et seq.
}

A \& C R. de Dir. Administrativo e Constitucional, Belo Horizonte, ano 4, n. 15, p. 149-179, jan./mar. 2004 
E não se diga que com a Restauração $(1640),{ }^{9}$ por estar a Coroa mais preocupada à mantença da colônia em face das invasões estrangeiras, houve um incremento administrativo do país, o que não se fez notar significativamente em termos de concepção e formação de um interesse nacional, matéria somente aprofundada a partir do século XIX, com a vinda da família real para nosso território.

De uma certa forma, pode-se aceitar a tese de que isto ocorreu em face da própria insipiência administrativa da cultura monárquica portuguesa, não muito afeita às questões de administração racional e prospectiva do Estado, decorrência, em muito, da relação patrimonialista que mantinha com a coisa pública. ${ }^{10}$

Veja-se que é o Poder Executivo nesta história que sempre esteve fortalecido, com poderes muitas vezes excessivo e ditatorial, como foi o caso do Conselho de Estado criado no âmbito do art. 137, da Constituição de 1824, com função de assessoramento em matérias relevantes da Coroa, seja de índole política, seja de ordem administrativa. Esta instituição nasceu visceralmente ligada à figura do Imperador, com o objetivo de suprir a ausência de responsabilidade do monarca, transferida para os conselheiros, os quais responderiam pelos conselhos que formulassem, em contrariedade à lei e ao interesse do Estado, desde que manifestadamente dolosos. ${ }^{11}$

Tal cenário foi focando o tema da Administração Pública na ótica do Executivo, cabendo a ele as principais ações públicas que estivessem vinculadas a interesses comunitários — notadamente serviços e subsídios ao mercado.

A par disto, não se pode dizer que foi sempre tranqüila a posição meramente ativista do Estado Executivo Administrador, eis que dentro do próprio Poder Instituído sempre houve disputas por espaços de poder funcionários públicos para tal mister. Ver o texto de BASTOS, Aureliano Cândido Tavares. A Província: estudo sobre a descentralização no Brasil. Brasília: Nacional, 1970, p. 37.

${ }_{10}$ Conforme pode-se extrair do trabalho de FAORO, Raymundo. Os Donos do Poder. Rio de Janeiro: Globo, 1984. Há aqui também uma certa matriz liberal clássica, notadamente a de LOCKE, John. The Second Tratiese of Civil Governament. Berckley: U.P. Berckley, 1980, p. 83, quando afirma que todos, tendo ou não tendo propriedade, no sentido comum, estão incluídos, como interessados na preservação das próprias vidas e liberdades. Ao mesmo tempo, apenas os que têm fortuna podem ter plena cidadania, por duas razões: apenas esses têm pleno interesse na preservação da propriedade, e apenas esses são integralmente capazes de vida racional - aquele compromisso voluntário para com a lei da razão - que é a base necessária para a plena participação na sociedade civil.

${ }^{11}$ Conforme SOUSA, António Francisco de. Fundamentos Históricos de Direito Administrativo. Lisboa: Editores Associados, 1925, p. 81 et seq. É de se registrar que, durante a Regência, adveio o Ato Institucional de 12 de agosto de 1834, de inspiração liberal e federativa, diploma legal que, em seu art. 32, pura e simplesmente extinguiu o Conselho de Estado, considerado um órgão conservador, auxiliar do Imperador. O Conselho de Estado funcionava em reunião plena, sob a presidência do Imperador, ou em quatro seções, divididas em negócios do império, negócios da justiça e estrangeiros, negócios da fazenda, negócios da guerra e marinha.

A \& C R. de Dir. Administrativo e Constitucional, Belo Horizonte, ano 4, n. 15, p. 149-179, jan./mar. 2004 
e de ação. Um exemplo muito claro disto é que, embora o art. 169, da Constituição de 1824, reproduzisse a dicção do referido art. 135, da Carta portuguesa, não ocorreu a construção de um sistema administrativo específico para o país, justamente pela ausência de justiça administrativa independente, tudo agravado pelas vicissitudes pelas quais passou o Conselho de Estado, considerado uma corporação oligárquica, rival dos Gabinetes Ministeriais, a conspirar contra ele, quando não amoldavam às suas conveniências políticas e interesses partidários. ${ }^{12}$

Aliado a isto, ainda contou o país, nos primórdios do século XIX, com uma noção e práticas de administração pública por demais frágeis, no que tange mesmo a rotinas e procedimentos gerenciais dos interesses e recursos públicos.

Mesmo após a instalação do Governo Provisório, conservou o poder central grande soma de autoridade, tanto que as Assembléias Provinciais foram dissolvidas, por decreto de 20 de novembro, ficando os governos locais, enquanto não houvesse a Constituição, com várias funções que poderiam ser restringidas, ampliadas e suprimidas, tendo os governadores assumido papel de simples delegados do Governo Provisório. O princípio federativo vigente era meramente formal, haja vista que prevalecia tão somente a soberania da União e a dos Estados-Membros, cada qual inatacável na órbita de sua competência, ficando os Municípios restritos ao âmbito de ações executoras das disposições cogentes, a despeito de estar prevista na ordem constitucional vigente a sua autonomia para gerir o interesse local (art.68, da Constituição de 1824).

Em verdade, ao longo do período de toda a República Velha, a Administração Pública brasileira padeceu de frágil estruturação institucional, e isto porque os chefes do Poder Executivo, dos três níveis federativos, em regra, eram eleitos de maneira pouco séria, decorrência dos vínculos mantidos com as oligarquias locais, vinculadas, por sua vez, à Presidência da República, formando uma rede política de interesses que se alojava e refletia na atuação administrativa.

Aqui, sequer se cogitava da participação social ou representativa da comunidade, eis que tal tarefa estava restrita aos cânones e mecanismos institucionais da política estatal.

Assim se desenvolveu a Administração Pública praticamente até o

final da década de 1980, com avanços e recuos institucionais, maiores em 12 Interessante neste sentido o texto de LEAL, Hamilton. História das Instituições Políticas do Brasil. Brasília: Ministério da Justiça, 1994, p. 330.

A \& C R. de Dir. Administrativo e Constitucional, Belo Horizonte, ano 4, n. 15, p. 149-179, jan./mar. 2004 
determinados momentos (como na era Vargas), ou menores (como ao longo do regime militar).

A partir da Constituinte e mesmo da Constituição de 1988, novos ares institucionais foram se forjando, notadamente no que tange às concepções de poder político-formal, não alterando significativamente a forma de exercício deste poder e suas manifestações mais cotidianas, eis que, embora a democracia brasileira ainda se encontre em processo de consolidação, na verdade ela tem experimentado um déficit no modo de seu funcionamento, haja vista que o que mais a identifica é um conjunto de procedimentos de administração estatais formalizados e técnico-burocráticos que se fecham às expectativas e demandas sociais. ${ }^{13}$

É de se notar que este déficit atinge tanto a relação Estado e Sociedade como Estado e Governo, eis que é explícita a preponderância do Poder Executivo em face dos demais poderes, tendo como justificativa tanto os poderes constitucionais que possui, como em razão da mobilidade política e de ação governamental que imprime nas relações hodiernas mais comuns, muitas vezes desconsiderando os Poderes Legislativo e Judiciário. Todavia, como não temos tempo neste ensaio de abordar estas relações endógenas que os poderes estatais mantêm entre si, cumpre verificar de que forma tem se constituído a relação Estado e Sociedade, principalmente a partir dos seus pressupostos informacionais e constitucionais, para então se verificar que limites e desafios se impõem no seu particular, com fulcro em algumas contribuições habermasianas.

\section{Estado e Sociedade Democrática de Direito: uma análise habermasiana}

Em termos históricos no Ocidente tem se aceitado que, ${ }^{14}$ durante o pós-guerra do século XX, os Estados das sociedades capitalistas desenvolvidas mais aguçaram do que abrandaram os distúrbios sociais e políticos então existentes (étnicos, raciais, religiosos e econômicos). Além disso, eles construíram sistemas de seguridade social com ajuda de burocracias que, centradas na assistência pública do Estado, não serviram propriamente como

\footnotetext{
${ }^{13}$ Neste sentido ver o texto de VIANNA, Luiz Werneck (Org.). A Democracia e os Três Poderes no Brasil. Belo Horizonte: UFMG, 2002, p. 8.

${ }^{14}$ Estamos falando das matrizes teóricas que vamos adotar nesta pesquisa, dentre as quais: COX, Raymund. Economic Globalization and the Limits to Liberal Democracy. In: McGREW, Antony (Ed.). The Transformation of Democracy? New York: Polity Press, 1997, p. 49-72; HELD, David. Democracy and the Global Order. New York: Polity Press, 1995, p. 99 et seq.; OFFE, Clauss. Demokratie und Wohlfahrtsstaat: Eine Europaeische Regimeform Unter dem Stress der Europaeischen Integration. Frankfort: Streek, 1998, p. 99-136.
} 
resguardo para seus clientes/cidadãos. Ao longo do terceiro quartel de nosso século, porém, o Estado social na Europa, e em outros países da Organização para a Cooperação e Desenvolvimento Econômico (OCDE), compensou em grande parte as conseqüências indesejadas de um sistema econômico altamente produtivo. É uma das poucas vezes que o capitalismo não impediu, antes possibilitou, que se tentasse cumprir a promessa republicana da inclusão igualitária dos cidadãos — única forma de superação do flagelo da guerra. ${ }^{15}$ Daí decorreram profundas transformações na compreensão do fenômeno político e governamental, dirigido à inclusão dos destinatários das ações de Estado à sociabilidade mais igualitária no processo de tomada de decisões, ${ }^{16}$ questões estas insertas nos textos constitucionais hodiernos, em especial, na Carta Política brasileira de 1988.

$\mathrm{Na}$ verdade, o conjunto de fenômenos acima caracterizados altera mesmo a própria compreensão de Constituição, outorgando-lhe muito mais que um significado meramente dogmático-formal de norma posta, pois que reconhecendo-a como pacto político-social instituidor da civilidade e das condições de sociabilidade e desenvolvimento das relações sociais, a partir de determinados postulados/premissas necessariamente vinculantes. ${ }^{17}$ Nesse sentido, quando compreendemos o texto de nossas Constituições como elemento material da realização de uma sociedade socialmente justa, a idéia da autolegislação, segundo a qual os destinatários das leis devem ser entendidos ao mesmo tempo como seus autores, ganha a dimensão política de uma sociedade que atua sobre si mesma.

Se ao construírem o Estado social na Europa do pós-guerra, políticos de todas as correntes se deixaram guiar por essa compreensão dinâmica do processo democrático, hoje temos consciência de que essa idéia só foi implementada, até agora, dentro dos moldes do Estado Social. ${ }^{18}$ Mas, quando o Estado Nacional, no contexto modificado da economia e da sociedade mundiais, chega aos limites de sua eficiência (em razão de suas insipiências vocacionais, operacionais e eficaciais), ${ }^{19}$ põem-se em xeque, com essa forma organizacional, tanto a domesticação política de um capitalismo

\footnotetext{
${ }^{15}$ Conforme o texto de FRIEDRICH, Carl J. Authority, Reason and Discretion. New York: Harvard University Press, 1998, p. 92.

${ }^{16}$ Conforme SCHONBERGER, Roland Jordan. Legitimate Expectations in Administrative Law. Oxford: Oxford Press, 2000.

17 Conforme XESTA, Fernando; VAZQUEZ, Ernesto. La Orden Civil de la Republica. Ciudadania y distincion en el Estado igualitario. Madrid: Civitas, 2001, p. 92. Também ver o texto de ENTERRÍA, Eduardo García de. Democracia, Jueces y Control de la Administración. Madrid: Civitas, 2001.

${ }^{18}$ Concordamos, neste sentido, com AGERE, Saul. Promoting Good Governance: principles, practices and perspectives. London: Martheson, 2002, p. 81/118.
}

A \& C R. de Dir. Administrativo e Constitucional, Belo Horizonte, ano 4, n. 15, p. 149-179, jan./mar. 2004 
global desenfreado quanto o exemplo único de uma ampla democracia que funciona sofrivelmente.

O Estado, agrilhoado ao sistema econômico transnacional, abandona seus cidadãos à afiançada liberdade negativa de uma competição mundial e limita-se, quanto ao mais, a pôr regularmente à disposição do cenário político e econômico infra-estruturas que tornem atraente sua própria posição sob a perspectiva da rentabilidade e fomentem atividades empresariais. Ao lado disto, uma questão igualmente inquietante impõe-se em vista do futuro da democracia, a saber, os procedimentos e ajustes democráticos, que conferem aos cidadãos unidos a possibilidade de atuação política sobre suas condições sociais de vida, o que se tem esvaziado à medida que o Estado Nacional perde funções e espaços de ação, sem que surjam para tanto equivalentes mecanismos de gestão do público, cada vez mais restrito aos termos de acepções corporativas de interesses privados. ${ }^{20}$

Mesmo no plano nacional as dificuldades de gestão das demandas sociais tem-se agudizado, de um lado, em face da forma centralizada com que a Administração Pública gerencia o cotidiano destas demandas, valendose do pressuposto de que detém a autoridade absoluta sobre tais ações, impondo-se - paternalística e assistencialmente - como a única capaz de demarcar prioridades e políticas públicas, bem como executá-las, sempre protegido/vigiado pelo princípio da Legalidade; ${ }^{21}$ de outro lado, em face da apatia política de grande parte da sociedade civil, que não compreende a administração dos seus interesses como compromisso seu, mas outorgado - na democracia representativa - a outrem, ao Estado, valendo-se de uma concepção fragmentada e exclusivista de espaço público e privado. ${ }^{22}$

Por tais razões, o debate que propomos tem uma dupla perspectiva: (1) a que diz respeito à concepção de Estado Administrador contemporâneo e seus fundamentos filosóficos e políticos; (2) a que diz respeito à ${ }^{19}$ Como muito bem aborda o texto de BETANCOR, August. Las Administraciones Independientes: um reto para el Estado social y democratico del Derecho. Madrid: Siglo Veinteuno, 2002, p. 34 et seq.

20 Já está notadamente demonstrada hoje a pertinência ainda do modelo do Estado Nacional, rearranjado em face das novas demandas que exsurgem cotidianamente, eis que base política de gestão indispensável à cidadania. Em outras palavras, o Estado Nacional não deve cumprir somente um papel reativo em vista das condições de utilização do capital de investimento, mas também um papel ativo em todas as tentativas de qualificar os cidadãos da sociedade e capacitá-los à competição. A nova política social não é menos universalista do que a antiga. Mas ela não deve, em primeiro lugar, servir de resguardo contra os riscospadrões do trabalho, e sim dotar as pessoas com qualidades empreendedoras típicas de "realizadores" que saibam cuidar de si próprios. Nesse sentido ver o texto de YOUNG, Martin. Inclusion and Democracy. Oxford: Masters, 2002, p. 64.

${ }^{21}$ No sentido de que a Administração Pública só pode agir/fazer aquilo que a Lei/Direito permite, enquanto que o cidadão pode fazer/agir tudo aquilo que a Lei/Direito não proíbe. Abordamos esta perspectiva em nosso livro LEAL, Rogério Gesta. Hermenêutica e Direito: considerações sobre a Teoria do Direito e os Operadores Jurídicos. 2. ed. Santa Cruz do Sul: Edunisc, 1999.

22 Tratamos este tema no livro LEAL, Rogério Gesta. Teoria do Estado: cidadania e poder político na modernidade. 2. ed. Porto Alegre: Liv. do Advogado, 2001. 
caracterização da Cidadania enquanto ator social constitutivo do poder político e do seu exercício, também a partir de sua configuração filosóficopolítica hodierna.

Entendemos que os níveis de complexidade que apresenta a sociedade contemporânea estão a exigir a revisão dos paradigmas que informam classicamente o problema da Administração Pública (reduzida a aspectos técnico-burocráticos de competência exclusiva do aparelho estatal). ${ }^{23}$ Para tanto, estamos propondo, como referencial teórico alternativo a este modelo clássico, a contribuição de Jürgen Habermas, notadamente no que tange à Teoria Procedimental da Democracia e seus pressupostos informativos, quando procura aferir, dentre outras coisas, quais as condições e possibilidades do Direito (e para a pesquisa, notadamente o Direito Administrativo) cumprir com uma função de integração social naquelas sociedades.

Em um texto clássico seu, Habermas sustenta que a deliberação pública, realizada fora do âmbito estatal, constituiria a base de legitimação para a ação política. Este espaço, ao menos em termos hipotéticos, permitiria a todos os potencialmente envolvidos poder opinar e interagir comunicativamente antes que uma decisão fosse adotada. Desta forma, a livre circulação da informação e do alongamento das oportunidades educativas erigir-se-iam em elementos nodais que explicariam a aparição desta esfera de autonomia, tudo isto tendo como motivação a implementação de condições histórico-sociais que possibilitariam a emergência, expansão e transformação de uma esfera pública que ele chama de burguesa, centrada que sempre esteve nas instituições tradicionais de representação política forjadas no âmago da experiência estatal moderna. ${ }^{24}$

Segundo a perspectiva do autor, ao que nos filiamos, um conjunto crescente de organizações e movimentos societais estariam enriquecendo a comunicação e o debate nas sociedades contemporâneas, revitalizando de forma substantiva a esfera pública. Estes novos âmbitos permitiriam a

${ }^{23}$ A teoria mais tradicional do Direito Administrativo tem insistido na idéia de que ele serve, fundamentalmente, às atividades estatais (executivas, legislativas e judiciais) e de governo. De uma maneira mais sofisticada, trabalhando com conceitos múltiplos, por exemplo, Augustín Gordillo, em seu Tratado de Derecho Administrativo. Buenos Aires: Fundación de Derecho Administrativo, 1998, insiste na concepção de que o Direito Administrativo (ou a função administrativa) diz respeito, fundamentalmente, às ações estatais tradicionais. No Brasil, Diogo de Figueiredo Moreira Neto, em sua obra Curso de Direito Administrativo. Rio de Janeiro: Forense, 1996, p. 04, é taxativo em afirmar que: é comum, por isso, num primeiro vislumbre sobre o Direito Administrativo, conotá-lo principalmente às regras de funcionamento do Estado, enquanto que o Direito Constitucional seria, precipuamente, a disciplina das regras de sua estruturação. Assim, de uma certa forma, o conceito de gestão pública tem-se sintetizado como um conjunto harmônico e sistêmico de princípios jurídicos que regem os órgãos, os agentes e as atividades públicas tendentes a realizar concreta, direta e imediatamente os fins desejados pelo Estado - Nesse particular, há uma reflexão de FREITAS, Juarez. $A$ Interpretação Sistemática do Direito. São Paulo: Malheiros, 1995.

${ }^{24}$ HABERMAS, Jürgen. Mudança Estrutural da Esfera Pública. Rio de Janeiro: Civilização Brasileira, 1988, p. 39.

A \& C R. de Dir. Administrativo e Constitucional, Belo Horizonte, ano 4, n. 15, p. 149-179, jan./mar. 2004 
articulação de uma pluralidade de enfoques culturais e sociais, o que levaria a reforçar a idéia de crítica e controle do poder e aprofundar a democracia, fazendo surgir, por sua vez, um fator de integração social alternativo, baseado no diálogo e não na dominação (ora simulada, ora explícita).

Nesta mesma direção, mais contemporaneamente, autores como James Bohman têm dado continuidade a este tipo debate, ${ }^{25}$ sustentando que a deliberação e o consenso seriam termos chaves à hora de definir a democracia e a política de governo ou de gestão, revelando-se fundamental que as razões de Estado e de cada grupo que o compõe possam resultar convincentes para o restante da cidadania, que tradicionalmente não participa diretamente do governo ou da gestão, ao menos no plano executivo ou legislativo do seu evolver, sem que para isto ninguém seja obrigado a abdicar de suas próprias opiniões e concepções de bem.

A partir de tais reflexões, o processo deliberativo levaria os cidadãos a ter de justificar suas decisões e opiniões apelando, em alguma medida, a interesses comuns, e argumentando com proposições assertóricas que todos pudessem aceitar no debate público, a partir do espaço efetivo que possuem para discordar. Em outras palavras, uma decisão coletiva sobreviria tão somente a partir de sua justificação por meio de razões públicas, expostas ao tensionamento da crítica e do falseamento. ${ }^{26}$

Aceitar estas premissas habermasianas implica trabalhar com a tese de que, num processo político-deliberativo de gestão de interesses comunitários, as pessoas devem estar abertas à força dos argumentos (lingüísticos, simbólicos e fáticos), preparadas para deixar de lado seus pontos de vista iniciais, quando vêem o benefício para a comunidade em seu conjunto, e isto pelo simples fato de que um sistema de discussão pública exige que as pessoas utilizem discursos que levem em conta a dimensão pública de sua inserção e os efeitos multifacetados do seu impacto no meio em que interagem. Em outras palavras, a necessidade de alcançar um compromisso única maneira de atingir racionalmente um convívio societal emancipador - forçaria cada participante a encaminhar suas propostas sobre a rubrica de princípios gerais ou considerações políticas que os outros pudessem aceitar/discordar. ${ }^{27}$

De uma certa forma, estamos convencidos de que neste modelo de deliberação, fundado na premissa de melhor formação e informação

\footnotetext{
${ }^{25}$ BOHMAN, James. Public Deliberation: Pluralism, Complexity, and Democracy. Boston: Madinson, 2002, p. 13. ${ }^{26}$ Id., p. 188
}

A \& C R. de Dir. Administrativo e Constitucional, Belo Horizonte, ano 4, n. 15, p. 149-179, jan./mar. 2004 
socialmente construída, a condição de cidadania restaria melhor preparada para a adoção de decisões relevantes, isto em face do modelo tradicional de representação política institucional moderna, em que os espaços de discussão, deliberação e execução ocorreriam mediados por instrumentos e mecanismos às vezes artificiais em termos de identidade e presentação social.

Os indivíduos que participam de um processo deliberativo a partir da proposição que se está apresentando, em tese, teriam potencializadas as suas percepções sobre o que efetivamente querem, sobre quais são realmente os seus desejos e objetivos; perceberiam com maior nitidez suas preferências antes de chegar à instância de ter de tomar uma decisão ou escolher uma política concreta de vida e gestão. ${ }^{28}$

Então, através do processo de lavagem e filtragem de preferências que resulta do debate público - entre atores públicos —, o número de opções viáveis se reduziria, porém sem empobrecê-lo qualitativamente; a discussão aberta permitiria simultaneamente enriquecer em potencial a gama e o conteúdo das opções e, por sua vez, delimitariam de forma mais pontual o espectro àquelas que se tornariam aceitáveis para o conjunto de participantes.

Numa outra perspectiva, a deliberação pública, fundada numa interlocução cotidiana pelos atores sociais que efetivamente estão envolvidos no processo político de constituição do espaço cívico e republicano da civilidade, pode ter também um efeito transformador das crenças e opiniões destes participantes, ${ }^{29}$ e assim podem produzir-se melhores decisões públicas, no sentido de serem refratárias das demandas da maior parte quantitativa da população atingida. Estamos dizendo, com Klaus Günther ${ }^{30}$ que em um sistema de livre expressão racionalmente fundada, a exposição de múltiplas perspectivas oferece um quadro mais completo das conseqüências dos atos sociais, auxiliando na construção de melhores normas, melhores leis, melhores políticas públicas, etc.; ou seja, um processo deliberativo, que funcione sob o fundamento da inclusão intersubjetiva ${ }^{27}$ Como quer COOKE, Maeve. Language and Reason: a study of Haberma's pragmatics. Cambridge: MIT, 2000, p. 82.

${ }^{28}$ A partir da dinâmica do processo, as posições podem e invariavelmente mudam, revisam-se; a renegociação e a reespecificação tornam-se uma constante. As razões, ao serem testadas pelo enfrentamento e debate público, podem reformular-se, desde que fundadas em níveis cognitivos de compreensão e reflexão autônomos.

${ }^{29}$ Podemos citar aqui, de forma exemplificativa e guardadas as proporções, do depoimento do orçamento participativo em Porto Alegre, eis que ele operou mudanças na credibilidade e mesmo na concepção negativa de poder público historicamente construído pelo país. Neste sentido, é interessante o texto de HABERMAS, Jürgen. On the Pragmatics of Social Interaction. Cambridge: MIT, 2002, p. 23 et seq.

${ }^{30}$ GÜNTHER, Klaus. The Sense of Appropriateness: aplication discourses in morality and law. New York: State University of New York, 1999, p. 217.

A \& C R. de Dir. Administrativo e Constitucional, Belo Horizonte, ano 4, n. 15, p. 149-179, jan./mar. 2004 
dos seus operadores, não precisa negar ou mesmo afastar a experiência da representação política, mas ampliá-la a extensões cada vez maiores, fazendo com que os resultados políticos de ações cotidianas respondam aos desejos e aspirações efetivamente populares e massivas.

Como afirma Avritzer, ${ }^{31}$ a deliberação pública é uma das muitas atividades cooperativas que demanda uma pluralidade, e não a nega, em nome de uma unidade artificial e totalitária de pensamento único; sua meta é resolver problemas junto com outros que têm perspectivas, preferências e interesses distintos, e em face disto precisam estar todos envolvidos, ativamente, no processo fenomenológico de concretização das respostas às suas demandas. A constante interação dialética entre culturas e concepções de mundo diferentes em uma grande esfera comum de cidadania enriquece a todos, porém, se e somente se houver práticas cotidianas de exercício do debate comunitário, sistematizado ou não, isto porque tal fato demanda uma mudança de comportamento também e principalmente social, haja vista a tendência da cidadania brasileira em se manter em uma condição de consumidora dos favores estatais (Estado este figurando como grande fornecedor dos resultados prontos e acabados), cabendo-lhe tão somente se satisfazer com eles e, mais que isto, aceitá-los sem qualquer contestação ou crítica.

Ocorre que a forma de gestão pública comunicativa que estamos propondo exige um mínimo de condições subjetivas e objetivas dos seus interlocutores, sob pena das falas enunciadas e trocadas serem coatadas por circunstâncias exógenas e endógenas à comunicação, tais como as insuficiências formativas e de discernimento dos homens comuns do povo, associado com o alto grau de profissionalismo e burocratismo das elites dominantes que assaltaram o Estado, ou, ainda, dos tecnoburocratas que instrumentalizaram ideológica e operacionalmente os aparelhos estatais, como mecanismo de alcançar projetos muito mais corporativos e individuais do que comunitários (como já referimos anteriormente).

Onde se fizer ausente a capacidade de manifestação da vontade do cidadão como artífice de sua própria história, em face de sua insipiência política e administrativa material e subjetiva, falecendo-lhe forças e perspectivas sobre os termos e possibilidades de gestão que circunvizinha seu cotidiano, isto só reforça a situação de anomia societal no âmbito do poder institucionalizado e de seu exercício, em todas as suas dimensões (legislativa,

\footnotetext{
${ }_{31}$ AVRITZER, Leonardo. Sociedade Civil: além da dicotomia Estado-Mercado. In: AVRITZER, Leonardo (Org.). Sociedade Civil e Democratização. Belo Horizonte: Del Rey, 1994, p. 52.
}

A \& C R. de Dir. Administrativo e Constitucional, Belo Horizonte, ano 4, n. 15, p. 149-179, jan./mar. 2004 
executiva e jurisdicional), fortificando, por ato reflexo ou convexo, a situação confortante dos encastelados nas hordas do Estado Soberano. Decorrência disto é que, mesmo naquelas circunstâncias em que há uma previsão formal de participação política, ela não é exercitada material e eficazmente pelo fato de estar marcada pela manipulação e pelo esvaziamento provocado pela ausência daquelas condições mínimas necessárias à comunicação e entendimento.

Podemos falar, a título exemplificativo, das experiências (umas exitosas outras não) dos conselhos populares que foram criados a partir da edição da Carta Constitucional de 1988, tais como os múltiplos Conselhos Municipais da Cultura, do Transporte Urbano, da Mulher, da Criança e do Adolescente, do Meio Ambiente, etc; assim também os Conselhos Regionais de Desenvolvimento, que em nível estadual vêm mobilizando um contingente cada vez maior de pessoas para o debate público das grandes questões que afetam as administrações públicas em todo o país. Acontece que, não raro, a comunicação que se instala nestes espaços de cidadania é deveras exíguo, quiçá ficcional, pelo fato de que não há um processo de discussão democrático, fundado em momentos e mecanismos de envolvimento orgânico dos seus partícipes, eis que geralmente se dão de forma pré-ordenada e com pautas decisionais já estabelecidas, com baixíssimos níveis de reflexividade para com os membros da comunidade atingidos pelas decisões tomadas e executadas.

Por tais razões não cremos que seja suficiente tão-somente criar novos espaços públicos para a deliberação, espaços que os participantes possam usar não apenas para expressar novas razões públicas, mas também para restaurar a amplitude da esfera pública e fazê-la mais inclusiva, porque tais espaços já foram constituídos, ao menos de forma embrionária, pelos antigos movimentos sociais urbanos e rurais - a despeito de um tanto que desarticulados —, e pelos novos movimentos sociais, agora alcançados por marcos normativos/institucionais que os reconhecem como sujeitos políticos e até sujeitos de direito. ${ }^{32} \mathrm{E}$ isto não é suficiente porque já alertamos para as armadilhas em que estes atores recorrentemente se vêem envolvidos, armadilhas da racionalidade estratégica e instrumental que informam os comportamentos pragmáticos dos políticos de plantão e profissionais, criando um universo enclausurado de expedientes, rotinas e prerrogativas excludentes de quaisquer neófitos que pretendam se aproximar dos temas 32 Estamos falando das organizações não-governamentais e das atividades de voluntariado, todos vindo ao encontro da abertura ainda mais tensional do espaço público, inclusive o estatal.

A \& C R. de Dir. Administrativo e Constitucional, Belo Horizonte, ano 4, n. 15, p. 149-179, jan./mar. 2004 
cujas competências já estão dimensionadas pela ordem jurídica e política vigente, afastando todo aquele que não reza pela mesma cartilha, ou não é iniciado no universo lingüístico que lhes são próprios.

Não basta, pois, confiarmos cegamente na tese — por vezes romântica - de que a formação inexorável de redes e de novíssimos movimentos sociais vão permitir agrupar recursos, capacidades e experiências de várias pessoas e grupos, e dar-lhes uma expressão coerente e, uma vez unificada, que poderão constituir-se em uma forma de compensar as desigualdades de recursos e a pobreza política que os atinge, emancipando-os dos grilhões a que estão submetidos. ${ }^{33}$ Este desafio não se restringe a uma instância/ momento espacial ou temporal de comunicação ou mobilização política, lingüística e cívica, mas ela precisa contar com um pressuposto epistemológico envolvendo a mobilidade política de que estamos falando, a saber: o de que são sempre as efetivas circunstâncias sociais (e suas variáveis econômicas, culturais e políticas) que vão indicar quais os procedimentos deliberativos e comunicativos que haverão de operar para os fins de constituição de um entendimento materialmente igualitário e inclusivo, voltado à participação da cidadania soberana, tanto por suas representações tradicionais como pelas formas livres (ordenadas ou não) de manifestação coletiva que as caracterizam. ${ }^{34}$

E qual a função do Estado e do Direito neste particular?

Jürgen Habermas, recentemente, ${ }^{35}$ defendeu a tese de que, ao longo do terceiro quartel de nosso século, o Estado Social na Europa e em outros países da OCDE (Organização para a Cooperação e Desenvolvimento Econômico) compensou em grande parte as conseqüências indesejadas de um sistema econômico altamente produtivo porém desequilibrador das relações sociais. Neste cenário, entende o autor que o capitalismo não impediu, antes possibilitou, que se cumprisse a promessa republicana da inclusão igualitária de todos os cidadãos, contando, dentre outras coisas, com uma nova dicção normativa institucional-constitucional.

De fato, o Estado constitucional democrático garante a igualdade também no

\footnotetext{
${ }^{33}$ Como quer, por exemplo, CASTELS, Manuel. La Sociedad de Redes. Madrid: Paidós, 2001, p. 119 e ss. Este autor, em nosso sentir, trabalha mais com a perspectiva de redes verticais de poder, produção e comunicação, deixando a descoberto uma avaliação sobre a necessidade de se horizontalizar tais ações políticas.

34 Estamos dizendo que, desde os movimentos organizados em torno de marcos jurídicos e lícitos existentes, voltados à pacificação das relações sociais buscando vias igualmente tradicionais de veiculação dos seus interesses, até os movimentos tidos como ilícitos ou vinculados à força física ilegítima, como o movimento dos sem terra, são hábeis para tensionar e provocar reflexões e interlocuções envolvendo esta matéria.

${ }^{35}$ HABERMAS, Jürgen. Nos Limites do Estado. Folha de S.Paulo, jul. 1999. Caderno MAIS!, p. 5-4.
} 
sentido de que todos devem ter a mesma oportunidade de fazer uso de seus direitos. John Rawls, hoje o teórico mais influente do liberalismo político, fala nesse sentido do "fair value" de direitos repartidos com paridade. Em vista dos desabrigados, que se multiplicam em silêncio sob nossos olhos, vem à memória a frase de Anatole France: não é suficiente que todos tenham o mesmo direito de "dormir sob as pontes". Quando compreendemos o texto de nossas Constituições nesse sentido material da realização de uma sociedade socialmente justa, a idéia da autolegislação, segundo a qual os destinatários das leis devem ser entendidos ao mesmo tempo como seus autores, ganha a dimensão política de uma sociedade que atua sobre si mesma. ${ }^{36}$

Ocorre que este modelo de Estado Social (e Nacional), no contexto modificado da economia e da sociedade mundiais, chega aos limites de sua eficiência, põe-se em xeque com essa forma organizacional da economia e dos mercados, submetendo-se à domesticação política de um capitalismo global desenfreado, o que gera o funcionamento ficcional da democracia representativa e seus mecanismos de operação política.

De qualquer sorte, o marco normativo-constitucional que inaugura os tempos hodiernos evidencia um parâmetro de concepção e ação estatal e social em direção a caminhos civilizatórios e de emancipação previamente demarcados, ao menos em suas linhas gerais. Tal parâmetro rompe com o paradigma reducionista da função reguladora meramente individual do direito (enquanto sistema e ordenamentos jurídicos), construída essencialmente sobre o conceito de direitos subjetivos. Como refere Habermas, esses direitos concedem a uma pessoa jurídica individual [Rechtsperson] âmbitos legais para uma ação guiada sempre pelas suas preferências próprias; assim, eles desligam de modo claro a pessoa legítima dos mandamentos morais ou das prescrições de outro gênero. Em outras palavras, sob o manto das fronteiras do permitido pela lei (ao menos na perspectiva liberal), ninguém é juridicamente obrigado a uma justificação pública dos seus atos. ${ }^{37}$

De forma instigante, uma das respostas — que é a que pretendemos explorar neste trabalho - sustenta que o Direito só pode cumprir a função de integração social se possuir (o sistema jurídico, os ordenamentos e as normas) um elemento de legitimidade que — por detrás de sua pura imposição coativa ${ }^{38}$ - necessita contar com uma aceitação/adesão dos atores sociais envolvidos e alcançados por ele. Tal legitimidade se apresenta de forma independente de sua imposição fática e depende do modo com que

36 Op. cit., p. 04.

37 HABERMAS, Jürgen. A Constelação Pós-Nacional. São Paulo: Littera Mundi, 2001, p. 144. Realça o autor que enquanto os direitos morais são derivados de obrigações recíprocas, as obrigações jurídicas o são da delimitação legal das liberdades subjetivas.

A \& C R. de Dir. Administrativo e Constitucional, Belo Horizonte, ano 4, n. 15, p. 149-179, jan./mar. 2004 
o Direito é forjado e se relaciona com o mundo da vida. ${ }^{39}{ }^{40}$ Significa dizer que o Direito só cumpre racionalmente sua função integradora quando é fruto de um discurso racional, de um processo constitutivo que se destaca pela inclusão dos sujeitos políticos que operam no cotidiano.

Os cidadãos de um Estado de direito democrático compreendem-se como os autores das leis que eles (na condição de endereçados) são obrigados a obedecer. Diferentemente do que ocorre na moral, no direito positivo os deveres valem como algo secundário; eles resultam apenas da compatibilidade dos direitos de cada um com os mesmos direitos de todos os demais. ${ }^{41}$

Em verdade, uma possível teoria da justiça em Habermas dá conta de que o Direito - assim como todas as suas manifestações, aqui destacaremos o âmbito da Administração Pública — tem uma dupla dimensão: fática e de legitimidade, sendo que ambas têm vínculos necessários e de dependência, eis que não basta a dimensão fática da validade do Direito para que ele se ponha como regulador/ordenador social, ${ }^{42}$ mais que isto, depende esta dimensão de uma base legítima de reconhecimento social da sua validade. De outra forma, implica reconhecer que o sistema jurídico que se encontra ancorado tão-somente em uma justificação lógico-formal (provido de legalidade positiva), pode não ser fruto da vontade geral da comunidade que alcança, impondo-se por argumentos não racionais (de força e do medo pelo castigo).

Na tradição liberal bem como na republicana, a participação política dos cida-

\footnotetext{
${ }^{38}$ Está presente aqui aquela idéia do Estado como possuidor da força física legítima, o que dá a autoridade e mesmo a legitimidade de suas ordens normativas, como muito bem demonstra WEBER, Max. Sociologia do Direito. São Paulo: Civilização Brasileira, 1998, v. 1, p. 83.

${ }^{39} \mathrm{O}$ conceito de mundo-da-vida, que impregna a teoria da evolução social de Habermas, foi tirado da fenomenologia de Edmund Husserl, do seu tratado sobre A Crise das Ciências Européias. Brasília: UnB, 1989 , p. 87. Para este autor, o mundo-da-vida é o contexto preliminar da prática natural da vida e da experiência do mundo; é um conceito oposto às idealizações que formam o campo de objetos das ciências naturais e a esfera imediatamente presente de realizações originárias. Veja-se que Habermas, no texto Teoria de la Acción Comunicativa. Madrid: Paidós, 2000, p. 81, sustenta que como um todo o mundo-da-vida só atinge o campo da visão no momento em que nos colocamos como que às costas do ator e entendemos o agir comunicativo como elemento de um processo circular no qual o agente não aparece mais como o iniciador, mas como produto de tradições nas quais ele está inserido, de grupos solidários aos quais ele pertence e de processos de socializações e de aprendizagem, aos quais ele está submetido. Após esse primeiro passo objetivador, a rede de ações comunicativas forma o meio através do qual o mundo-da-vida se reproduz.

${ }^{40}$ Conforme HABERMAS, Jürgen. Faktizität und Geltung. Beiträge zur Diskurstheorie des Rechts und des Demokratischen Rechtsstaats. Frankfurt: Verlag, 1994, p. 48. Acredita Habermas que quando os destinatários das normas não se sentem autores das mesmas, pela fato delas não serem forjadas num processo democrático efetivo, elas tendem a não ser majoritariamente cumpridas, resultando que tal ordenamento jurídico não exercitará a função de garantir a ordem e mesmo a coordenação/gestão das relações de forças.

41 HABERMAS, Jürgen. A Constelação Pós-Nacional. Op. cit., p. 128.

${ }^{42}$ Dimensionado pela fala da autoridade estatal, kelsenianamente demonstrada enquanto resultado da dicção institucional do poder. KELSEN, Hans. Teoría del Estado. Barcelona: Paidós, 1990, p. 93.
} 
dãos é compreendida em um sentido essencialmente voluntarioso: todos devem possuir a mesma chance de fazer valer de modo efetivo as suas preferências ou de expressar com comprometimento a sua vontade política, seja no intuito de seguir os seus interesses privados (Locke) ou para atingir o usufruto da autonomia política (J.S. Mill). Mas se nós, no entanto, atribuímos à formação democrática da vontade também uma função epistemológica, o seguir os interesses próprios e a efetivação da liberdade política ganham ainda a dimensão do uso público da razão (Kant). Então o procedimento democrático retira a sua força legitimadora não mais apenas - e nem sequer em primeira linha — da participação e da expressão da vontade, mas antes do acesso universal a um processo deliberativo cuja natureza fundamenta a expectativa de resultados racionalmente aceitáveis. ${ }^{43}$

Num tal modelo de normatividade jurídica pensado a partir da construção/adesão societal, os temas da soberania popular, do poder político, dos direitos humanos, da Administração Pública, da autonomia dos sujeitos, são remetidos para uma reflexão sobre a importância dos pactos sociais voltados à instituição de uma Sociedade Democrática e de um Estado Democrático. E isto porque os modelos de democracia representativa ou participativa institucional não têm dado respostas satisfatórias ao tema da participação popular na administração das demandas públicas emergentes, em nosso sentir, porque, primeiro, não contam com um adequado diagnóstico do fenômeno político das relações sociais contemporâneas (desconsiderando a complexidade dos múltiplos aspectos de sua configuração, o que perfunctoriamente demonstramos acima); segundo, porque efetivamente não possuem práticas democráticas de ação administrativa, haja vista a relação patrimonialista que os atores políticos tradicionais mantêm com o poder.

Em face de tudo isto é que estamos propondo a presente reflexão preliminar sobre a necessidade e mesmo a possibilidade de pensarmos estratégias para potencializar a Administração Pública como um efetivo espaço de interlocução, deliberação e execução compartida de políticas públicas. Vejamos quais os caracteres mais nucleares que tal proposta pode definir.

\footnotetext{
${ }^{43}$ HABERMAS, Jürgen. A Constelação Pós-Nacional. Op. cit., p. 140. Vai se revelando aqui a idéia de ética discursiva que perpassa a reflexão de Habermas, enquanto reconstrução da idéia kantiana de razão prática em termos de razão comunicativa. Em outras palavras, a idéia de Habermas implica uma reformulação procedimental do imperativo categórico kantiano, isto porque a validez construída como aceitabilidade racional não é algo que possa ser certificado de forma privada, mas está ligado a processos de comunicação nos quais as pretensões de cada um se provam argumentativamente por meio da ponderação de razões prós e contras. Se substitui assim a idéia de imperativo categórico kantiano por um procedimento de argumentação prática dirigido a alcançar acordos racionais entre aqueles que estejam sujeitos às normas em questão.
}

A \& C R. de Dir. Administrativo e Constitucional, Belo Horizonte, ano 4, n. 15, p. 149-179, jan./mar. 2004 


\section{Governabilidade democrática e participação política: possibilidades}

A Administração Pública no Brasil, assim com na maior parte dos países da América Latina, tem se pautado pela profunda indiferença em relação às aspirações e reais demandas da comunidade alcançada por suas práticas oficiosas, gerida por corporações que se apoderam do Estado e o transformam em aparelho ou instrumento de seus interesses privados.

Na verdade este Estado Transnacional tem desenvolvido estratégias de acumulação para o próprio mercado, garantindo um modelo de desenvolvimento e estabilidade da produção capitalista (especulativa ou não), desestruturando os espaços nacionais de conflito e negociação, minando a capacidade financeira e reguladora das instâncias federais, regionais e locais de seu território, o que aumenta a escala e a freqüência dos riscos sociais e estruturais do entorno em que opera. ${ }^{44}$

Apesar deste fato ser lugar comum, sempre é necessário que o lembremos para nos dar conta do preço que os cidadãos têm pagado por ficarem ausentes da esfera pública em que estão inseridos, ou deixarem que ela se transfigure em esfera privada, já que a inércia política que identifica boa parte da história da cidadania brasileira também é responsável por omissão, deixando que setores sociais mobilizados tomassem as rédeas do seu evolver.

Tal cenário, todavia, não nos leva à incredulidade em face da principal promessa da modernidade: a razão emancipadora, eis que, até aqui, o que temos visto imperar é fundamentalmente a utilização instrumental e estratégica da razão, voltada para os fins que acabamos de delimitar. Na verdade, estamos propondo um afastamento da cética perspectiva da primeira geração da Escola de Frankfurt ${ }^{45}$ e, com Habermas, acreditando que é possível operarmos a razão a partir de outros lugares e fundamentos, resgatando sua dimensão emancipadora, do entendimento à paz e à solidariedade, portanto, revelando sua função procedimental-valorativa, com as seguintes características: (a) observar os vetores axiológicos universais não metafísicos, como os direitos humanos e fundamentais; (b) partir e problematizar de forma permanentemente aberta e crítica as proposições

\footnotetext{
${ }^{44}$ Neste sentido, ver o texto de TIMOTHY, Mitchell. The Limits of the State: beyond statist approaches and their critics. Stanford: Stanford University Press, 2003, p. 39 et seq.

${ }^{45}$ Conforme o texto de JAY, Martin. La imaginación dialéctica: uma história de la Escuela de Frankfurt. Madrid: Taurus, 1974. Aquí demonstra o autor que Habermas, apesar de ter voltado à Frankfurt em 1964, como professor de sociologia e filosofia, foi gradativamente se afastando de seus mentores no Instituto. Em especial, o que começou a surgir como abordagem diferenciada de Habermas à teoria crítica
} 
assertóricas de todos os atores sociais que se encontram sob sua égide, numa perspectiva de entendimento e consenso, consciente da natureza permanentemente tensional de tal tarefa; (c) explicitar os argumentos de justificação e fundamentação que pretendem legitimar os modelos de organização social e comunicação política que se encontram na base de sua constituição.

A partir daqui, impõe-se o acatamento da diferença e do pluralismo do universo de interessados/alcançados pelas políticas públicas levadas à cabo pelo Estado Administrador e, com isto, garantir a diversidade, buscando a unidade na gestão dos interesses e bens assegurados pelo sistema jurídico vigente, rompendo com a fatispécie autoritária de poder e de modelo de Estado burocrata e decisor, até então hegemônica na formação dos quadrantes administrativos da coisa pública no Brasil.

O tema aqui é o que envolve a possibilidade de uma governabilidade democrática fundada na participação política, matéria que até há pouco vinha se apresentando como contraditória, haja vista o modelo vigente trabalhar com uma noção tímida - quiçá insuficiente - de soberania popular, prevalecendo a institucional-representativa do Estado. ${ }^{46}$ Esta possibilidade, desde o início deste século XXI, vem sendo tonificada pela idéia de Republicanismo, i.é., que a política constitui a forma de vida da comunidade e a idéia de que a liberdade e a democracia constituem formas de autogoverno desta comunidade, ${ }^{47}$ porém, carrega consigo duas aparentes e clássicas contradições, quais sejam: (1) a da participação social em face do aumento de complexidade administrativa do Estado Administrador; (2) a participação pública dos sujeitos sociais e a representação institucional vigente. ${ }^{48}$ Vamos avaliar cada uma destas questões.

\subsection{Participação social e complexidade administrativa}

As razões de justificação da tese de que a complexidade da administração pública dificulta a participação social é ideológica e se encontram em argumentos endógenos e exógenos à gestão da coisa pública.

\footnotetext{
foi, de uma certa forma, uma superação ao paradigma fatalista que a Escola tinha em razão da cultura industrial e da ideologia que se criara nela, pervertendo as promessas racionais da modernidade de emancipação e liberdade do homem. Neste sentido, emerge em Habermas o interesse em especificar as condições sob as quais as interações humanas estariam livres de dominação.

${ }^{46}$ Uma das fontes clássicas desta perspectiva é o Elitismo Democrático de matriz schumpeteriana, restringindo a soberania das massas a um procedimento de seleção governamental, elegendo os mais preparados às funções diretivas, coincidentemente os mais abastados. Conforme SCHUMPETER, Joseph. Capitalism, Socialism and Democracy. New York: Harper \& Brothers, 1989. Ver também o texto de ZIA, Onis. The Logic of the Developmental State. Princeton: Princeton Uriversity Press, 2002, p. 219.

47 BOZEMAN, Barry. All Organizatios are Public: bridging public and private organizations theories. San Francisco: Jossey Bass, 2001, p. 38.
} 
Os argumentos endógenos trabalham com a idéia de que o tema da administração pública possui um grau de complexidade e especificidade que vão desde sua dimensão gramatical/lingüística até a sua operacionalização, eis que conta com um universo categorial tão próprio e pontual que só é alcançado pelos já iniciados em sua ciência, deixando os incautos cidadãos comuns do povo sem compreensão sígnica dos seus enunciados e discursos, o que inviabiliza, por conseqüência, a compreensão de suas práticas, eis que decorrência da operacionalização daqueles conceitos e discursos. Em tal cenário, o que resta à sociedade é tão somente avaliar os resultados das ações e políticas públicas, sendo-lhe vedada o atingimento dos níveis de discussão e deliberação sobre a concepção/eleição daquelas ações e políticas — questões restritas às instituições competentes. ${ }^{49}$

Os argumentos exógenos versam sobre a idéia de que a participação social na gestão da coisa pública encontra limites cognitivos e institucionais, os primeiros, demarcados pela impossibilidade da comunidade política ter discernimento pleno dos temas que estão envolvidos no âmbito da administração pública, eis que destituída de conhecimentos adequados para tanto; os segundos, delimitados pela falta de organicidade institucional e política desta comunidade, capaz de lhe outorgar uma compleição física e institucional mínima para se mover e agir representativamente.

Ledo engano, a uma, porque estas teses partem de pressupostos equivocados e ultrapassados, quais sejam, a de que somente os mecanismos e instrumentos da democracia representativa (voto, partidos políticos, parlamento, etc.) é que têm a competência e legitimidade exclusiva à representação dos interesses sociais, a duas, o fato de que a sociedade civil contemporânea não consegue se articular/mobilizar em torno de suas demandas, a ponto de veicular propostas, ações e cobranças eficazes em termos de gestão da coisa pública; a três, que falta aos atores sociais hodiernos condições mínimas de compreensão dos atos da administração pública.

Veja-se que o modelo de democracia representativa clássico da Idade Moderna, fundado na idéia de representação política total, não conseguiu se desincumbir com total êxito das suas tarefas sociais e populares, transformando-se muito mais em espaços de composição de interesses

\footnotetext{
${ }^{48}$ Isto porque o republicanismo tradicional insiste em não rever seus conceitos rígidos de participação social através fundamentalmente do voto, e da participação política a partir dos partidos existentes no ordenamento jurídico vigente.

${ }^{49}$ Ver a título exemplificativo o texto de BOVERO, Michelangelo. Uma Grammatica della Democrazia. Millano: Trotta, 2002, p. 137 et seq.
} 
privados, apropriando-se do Estado e imprimindo-lhe feições meramente intermediativas dos projetos econômicos hegemônicos — por vezes agindo como gerenciador de tensões sociais limítrofes, promovendo ações públicas paliativas e assistencialistas, meramente contingenciais, sem tocar nas causas fundantes destes conflitos. ${ }^{50}$ Tais fatos levaram este modelo a uma crise de identidade (por que não se sabe a quem representam), de eficácia (porque sequer respondem por suas competências normativas), e de legitimidade (porque não são mais refratários às demandas sociais emergentes, agregadas e reprimidas).

No que tange à capacidade de articulação e mobilização da sociedade civil, temos visto nos últimos anos — notadamente desde a década de 1960 - que, até em face da ausência de políticas públicas promovedoras das suas demandas, houve um crescimento vertiginoso de associações civis, organizações não governamentais e atividades de voluntariado, todas voltadas à proteção de interesses coletivos, difusos e individuais homogêneos não atendidos pelo stablischment, ${ }^{51}$ o que modificou profundamente o perfil do tecido social e mesmo da relação do Estado com a Sociedade, criando-se canais de comunicação - na maioria das vezes tenso e truncado - voltados à demarcação de pautas de gestão não contempladas pela política oficial.

Por fim, esta capacidade de mobilização e organização social propiciou um processo de conscientização política gradual e em desenvolvimento dos novos movimentos sociais, já que necessitavam decifrar os códigos fechados da linguagem do poder e da administração, para os fins de buscar a implementação e promoção de suas prerrogativas garantidas pelo sistema jurídico operante.

De outro lado, trata-se de ficção ideológica a assertiva de que o universo temático da administração só pode ser abarcado a partir de sua linguagem ordinária, em nome da precisão técnica e da correção científica, eis que estes argumentos remontam a justificativas demasiadamente positivistas, cuja intenção é tão somente excluir do processo de cognição, compreensão, interlocução, deliberação e execução das ações consectárias, os não iniciados, criando um feudo lingüístico a partir do qual se exercitam as arbitrariedades de poder.

Abaladas as teses sustentadoras de uma Administração Pública cerrada sobre si própria, cumpre verificar se a participação pública dos sujeitos sociais

${ }^{50}$ Estamos falando dos programas de subsídios paternalistas dos governos em geral, no âmbito da produção rural, vale refeição, auxílio creche, auxílio desemprego, assentamentos de sem terra, etc.

51 Conforme demonstramos em nosso artigo: LEAL, Rogério Gesta. Gestão Pública Compartida e Organizações Sociais. In: Direitos Sociais e Políticas Públicas. Santa Cruz do Sul: Edunisc, 2001, t. I. p. 35/72. 
implica a negação da sua representação institucional.

\subsection{Participação pública dos sujeitos sociais e representação institucional}

É igualmente frágil a tese de que um excesso de participação da sociedade acarretaria desgaste às formas clássicas de representação política da democracia moderna, isto porque não são incompatíveis com os novos sujeitos sociais que são os grupos mobilizados de determinados setores da comunidade. Se é verdade que tais movimentos apresentam perfis organizacionais próprios, inserção específica na tessitura social e articulações particulares com o arcabouço de poder existente, não é menos real que eles também necessitam da esfera pública e institucional do debate de temas que lhes dizem respeito (por exemplo, dialogando com o Estado para obter dele demandas que lhes afligem).

Ao lado disto, temos claro e patenteado que as duas ambiências de articulação do político encontram-se ancoradas por justificativas racionais sustentáveis, a institucional, pela lógica da representação normativa e deliberacional dos que se encontram habilitados a tanto; a popular, pela lógica da presentação soberana do cidadão, detentor legítimo da vontade original criadora das instâncias oficiais do poder.

Acontece que o problema fundante é ainda o mesmo, qual seja, quem tem historicamente se apresentado como dominus do espaço público é muito mais o Estado Administrador, em face de sua racionalização tecnicista (e instrumental, por vezes), i.é., de separação entre o saber comum e o saber político, tornando uma técnica particular, aplicada a manutenção da unidade do reino ou da res publica,${ }^{52}$ do que as formas alternativas de presentação social — até porque estas também têm pecado por inércia e passividade política.

Vale aqui a advertência feita por Alba Zaluar, no sentido de que a crise financeira do Estado Providência nos países economicamente independentes reacendeu a preocupação com aquela parcela da população inativa e mesmo ativa que desenvolveu um certo vício da dependência estatal, tornando-se parasitas dos demais, ${ }^{53}$ destacando-se suas parcelas de responsabilidade social.

A proposta é, então, que o Estado Passivo Providência seja substituído pelo Estado 52 LIMONGI, Maria Isabel. Uma Gênese Inusitada do Estado. Revista de Sociologia e Política, Rio de Janeiro, v. 9, nov. 1997, p. 190. Adverte a autora aqui que a exigência da publicidade e transparência dos atos de governo impostas pelas Luzes não consegue romper totalmente com a retórica do segredo e da especialidade das falas/atos governamentais, sendo necessário pensarmos a razão de Estado como o vetor, não de uma arte de reinar tenebrosa, mas da iluminação dos mecanismos da vida coletiva.

A \& C R. de Dir. Administrativo e Constitucional, Belo Horizonte, ano 4, n. 15, p. 149-179, jan./mar. 2004 
Ativo Providência. Não haveria mais assistidos a socorrer, mas pessoas com diferentes utilidades sociais, cuja capacidade deveria ser aproveitada. Nele também a socialização radical dos bens e das responsabilidades. Uma nova concepção de solidariedade é mobilizada na ideologia desse Estado: não é nem a caridade privada, nem o bem-estar advindo dos direitos sociais, nem a mutualidade do solidarismo do século XX. (...) as políticas públicas deveriam se ocupar de prevenir a exclusão mais do que de reinserir os excluídos; de criar uma sociabilidade positiva mais do que de remediar a negativa, embora no quadro da crise atual o oposto tenha que ocorrer na política de reinserção. Os atores desse projeto seriam diferentes: não mais os sindicatos e o Estado redistribuidor, mas uma série de associações de diversos tipos, junto às quais o Estado ainda seria o principal ator do social, criando nova legitimidade para sua intervenção. ${ }^{54}$

É plenamente possível em face de tal quadro - e até necessário imaginarmos situações de cooperação entre Partidos Políticos, Parlamento, Poder Executivo e Movimentos Sociais organizados, eis que todos possuem, ao menos em tese, o mesmo móvel e objetivos: o interesse público — sempre tensional e conflituoso. ${ }^{55} \mathrm{~A}$ instância formal de representação comunitária pode e deve instituir um espaço permanente de interlocução com a instância informal de presentação desta mesma comunidade, e deles todos com o Estado Administrador, porém, mister é que tenhamos claro quais os pressupostos informativos que fundam tal diálogo, tema que passamos a abordar.

\section{Pressupostos fundacionais da Administração Comunicativa}

Os pressupostos fundacionais de uma Administração Pública Democrática e Comunicativa tomam como ponto de partida um conceito procedimental de poder político e social, em que há uma relação umbilical e necessária entre processo de democratização da sociedade e processo de transformação desta mesma sociedade, lócus privilegiado da produção de relações e das possibilidades conceituais e operacionais do poder. Tal ponto de partida implica reconhecer que o processo de democratização do poder e da sociedade é permanente e longo, mediado, de um lado, por uma linguagem e comunicação política includente e aberta, e de outro lado, pela interação de instituições políticas tradicionais, pelos valores da

\footnotetext{
${ }^{53}$ ZALUAR, Alba. Exclusão e Políticas Públicas: dilemas teóricos e alternativas políticas. Revista Brasileira de Ciências Sociais, São Paulo, v. 12, n. 35, out. 1997, p. 30.

54 ZALUAR, Alba, op. cit., p. 32.

55 Principalmente diante de um quadro político em que apenas a dimensão econômica dos direitos civis e sociais são parcamente assegurados, isto porque eles são introduzidos pelo Estado e no Estado para facilitar a institucionalização de um modelo de mercado e relações de produção. Neste sentido ver o texto de AVRITZER, Leonardo. Cultura Política, Atores Sociais e Democratização: uma crítica às teorias da transição para a democracia. Revista Brasileira de Ciências Sociais, São Paulo, ano 10, n. 28, 1995, p. 115.
}

A \& C R. de Dir. Administrativo e Constitucional, Belo Horizonte, ano 4, n. 15, p. 149-179, jan./mar. 2004 
esfera societária na qual se encontram estas instituições, e pelos movimentos sociais organizados ou espontâneos.

Em outras palavras, estamos falando de um novo contrato da civilidade, que não é mais contrato civil nem contrato civil com o Estado, mas um contrato de cada um com todos que fazem parte da comunidade nacional (quiçá internacional, em alguns aspectos). Este novo contrato justificaria as novas formas de legitimidade que ressaltam o caráter ainda nacional do Estado, no qual a violência exercida deve ser limitada, controlada e justificada; criaria as novas formas de solidariedade nas quais o Estado seria também o catalisador de inúmeros circuitos de reciprocidade e solidariedade que necessitam definição. Aqui, trata-se de reaproximação entre o social e o político, ou da repolitização dos laços sociais, ligando-os aos direitos sociais e à cidadania.

O problema que se coloca a esta mediação e interação é exatamente os seus princípios e fundamentos matriciais, dando as condições de exercício do poder - mais particularmente o exercício do poder administrativo em prol dos interesses comunitários-solidários. Estes princípios e fundamentos estão alojados, em nosso sentir, no catálogo axiológico estabelecido pelo sistema jurídico vigente, desde e prioritariamente a dicção constitucional hodierna no país, até os ordenamentos infra-constitucionais.

Estamos dizendo que os parâmetros valorativos a serem perseguidos pela República e Federação brasileira estão postos de forma induvidosa, e revelam-se suficientes para o cumprimento das promessas da modernidade: emancipação, autonomia, liberdade e igualdade do homem fundadas na sua capacidade de ser no mundo. A isto se encontra atrelada a Administração Pública, porém, este senso comum não tem se revelado suficiente para promovê-las e concretizá-las, porque faltam adesão institucional e social para tal desiderato. Para consegui-la de forma democrática, nada mais aconselhável do que o procedimento de compartilhar coletivamente ações a ela voltadas, a começar por ações cognitivas e compreensivas sobre o universo posto ao enfrentamento: interesses comunitários, prioridades públicas, políticas públicas, gestão administrativa, visando à constituição de pactos semânticos e pragmáticos definidores destas realidades voltados ao consenso e entendimento. ${ }^{56}$

A par disto, para operacionalizar tal perspectiva, é necessário construirmos uma linguagem comum capaz de ser codificada e compreendida pelo homem comum do povo, principal fonte e destinatário de toda e

A \& C R. de Dir. Administrativo e Constitucional, Belo Horizonte, ano 4, n. 15, p. 149-179, jan./mar. 2004 
qualquer ação administrativa estatal, ultrapassando, pois, os signos herméticos e nebulosos dos códigos lingüísticos jurídicos tradicionais, que se projetaram e mesmo demarcam à Administração Pública contemporânea, principalmente em sua vertente técnico-burocrática, o que impossibilitou a aproximação política dos seus termos e práticas por parte da cidadania em geral, enclausurando-os nas mãos dos já iniciados e institucionalizados agentes sociais e negando a natureza mediadora e interativa que deveria ter esta linguagem.

E é a própria Administração Pública que deve - em nosso sentir e destacadamente - criar condições à instituição de uma comunicação e linguagem decodificada e democrática, com o que permitirá a validação racional das questões normativas e operativas de suas ações - já não mais suas, mas de toda a comunidade - , isto porque tal validez passa a ser compreendida como dependente de um processo intersubjetivo, regulado por razões e por posições tomadas racionalmente. Esta medida permitirá ao menos metodologicamente - que Administrador e Administrado facilitem o processo de entendimento, visando o consenso, a partir do uso de uma linguagem que busca, agora, elucidar a própria linguagem administrativa em seus mecanismos de uso na comunicação cotidiana entre os participantes de uma comunidade; é a linguagem se apresentando como mediadora das relações intersubjetivas. ${ }^{57}$

Qualquer Administração Pública para se configurar como democrática e comunicativa precisa, então, contar/construir o maior número possível de adesão social legítima, adquirida através de ações comunicativas permanentes (tensionais e conflituosas em face de tratar de interesses eventualmente distintos) com todos os agentes envolvidos e alcançados pelo exercício do poder político - institucionais ou não. Ao mesmo tempo, pelo fato das ações administrativas cotidianas comportarem pretensões, sejam de verdade proposicional, de correção normativa ou veracidade subjetiva, devem elas

\footnotetext{
${ }^{56}$ Haja vista que estes conceitos e ações, tradicionalmente, vêm sido dados como verdades absolutas pela dicção do Estado Administrador.

${ }^{57}$ A linguagem, aqui, assume a função de mediadora entre os falantes, objetivando o entendimento, compreendido como um processo de obtenção de um acordo entre sujeitos lingüísticos e interativamente competentes. Neste sentido, ver HABERMAS, Jürgen. La Soberanía Popular como Procedimiento: un concepto normativo de lo publico. In: Jürgen Habermas: moralidad, ética y política. Madrid: Alianza Editorial, 1993. Para o autor, há em qualquer linguagem voltada à comunicação não coatada visando o entendimento autônomo e livre, pelo menos, quatro pretensões de validade que precisam ser justificadas simultaneamente: (a) pretensão de verdade, que exige o cumprimento das condições de existência do conteúdo proposicional, para que este possa ser verdadeiro; (b) a pretensão de retitude ou adequação, que exige do ato de fala que ele seja correto em relação a um contexto normativo vigente; (c) a pretensão de sinceridade, que objetiva tornar conhecidas as experiências e as vivências do falante, e, por fim, (d) a pretensão de que ato comunicativo seja inteligível, para que possa haver comunicação
} 
satisfazerem um requisito essencial: serem suscetíveis de fundamentação e crítica constantes, retroalimentadoras do controle e depuração social.

Por outro lado, não temos dúvidas (com Habermas) ${ }^{58}$ do caráter precário e contingencial do entendimento e do acordo conseqüente buscado/atingido por esta Administração Pública Comunicativa, aqui concebida como um processo, através de procedimentos, pois os êxitos consensuais para ações públicas pontuais nem sempre conduzem a cenários absolutamente estáveis, pelo contrário,

a estabilidade e a univocidade são mais a exceção na prática comunicativa cotidiana. Mais realista é a imagem que nos oferece a etnometodologia de uma comunicação difusa, frágil, constantemente submetida a revisão e só lograda por alguns instantes, em que os implicados se baseiam em pressuposições problemáticas e não declaradas, sempre movendo-se por tentativas desde logo naquilo que estão de acordo, para o seguinte. ${ }^{59}$

Isto se explica pelo simples fato do reconhecimento da complexidade que marca as relações sociais contemporâneas, sempre em permanente mutação e ampliação de suas demandas e conflitos, porém, o que se busca na Administração Púbica e com ela, é a garantia de um espaço público de enfrentamento de todas as particularidades deste cenário, acolhendo a diversidade e a diferença como elementos imprescindíveis para o debate, a deliberação e a execução das políticas públicas norteadoras das ações públicas voltadas à comunidade como um corpo político orgânico e ativo. É este plano de visibilidade plena e plana que deve marcar o novo modelo de gestão pública compartida, criando as condições objetivas e subjetivas para que a participação política da cidadania seja condição de possibilidade da Administração Pública Democrática de Direito.

\section{Considerações finais}

Ao longo deste trabalho, procuramos enfrentar o tema dos pressupostos epistemológicos e filosóficos que devem informar a Administração Pública no Brasil, aqui compreendida como fenômeno societal multidisciplinar, ultrapassando a perspectiva tradicional que a concebe como atividade meramente institucional de responsabilidade e competência exclusiva do Estado Administrador. Para tanto, fizemos uso da concepção habermasiana de Democracia Procedimental.

\footnotetext{
${ }^{58}$ Apud HABERMAS, Jürgen. Strukturwandel der Öffentlichkeit. Boon: Darmstadt, 1978, p. 49 et seq.

${ }^{59}$ ARAGÃO, Lucia Maria de Carvalho. Razão Comunicativa e Teoria Social Crítica em Jürgen Habermas. Rio de Janeiro: Tempo Brasileiro, 1992, p. 29.
} 
O conceito de democracia procedimental implica outros conceitos estruturais de Poder Político e de Participação Política, baseados numa sustentação teórica dual, relacionado não apenas com a formação da vontade política institucionalizada na dicção parlamentar, mas também com uma noção de esfera pública revitalizada, que realoca a um conjunto orgânico de arenas políticas informais, composta de velhos e emergentes atores/cidadãos, dialogicamente discursivas e democráticas, inovadoras competências soberanas de interlocução, deliberação, formulação e execução de políticas públicas sociais.

Esta democracia procedimental é um conceito que remete, em Habermas, para uma tensão inexorável, i.é., a oposição binária entre o plano formal e institucionalizado da democracia e os domínios informais de formação/execução da opinião pública. Esta noção de política democrática procedimental, assim, assenta-se igualmente numa teoria do discurso, cujo ideal regulador é um modelo de prática discursiva dialógica, face-a-face e orientada para o entendimento mútuo, através exclusivamente da força do melhor argumento. Este modelo de comunicação tem por objetivo descrever e interpretar a inserção do indivíduo num contexto intersubjetivo concreto, oportunizando-lhe constituir(-se) o mundo da vida, no caso particular, coresponsabilizando-se pela gestão dos seus interesses e da comunidade em que vive.

$\mathrm{O}$ argumento habermasiano, então e como vimos, centra-se nesta idéia de democracia procedimental porque envolve a todos e outorga a todos responsabilidades indissociáveis no processo de construção dos seus cotidianos: Our reflections from the standpoint of legal theory revealed that the central element of the democratic process resides in the procedure of deliberative politics. ${ }^{60}$ Por tais razões é que sustentamos que a Administração Pública precisa ser compreendida como processo democrático, ou seja, como o resultado de compromissos entre interesses públicos e privados concorrentes, o que implica que as regras deste processo político sejam responsáveis pela sua transparência e honestidade, e sejam justificadas através dos direitos humanos e fundamentais, como da concepção republicana de uma comunidade ética institucionalizada no Estado, em que a deliberação democrática se assenta num contexto cultural que garanta a comunhão de valores objetivada, por exemplo, no texto constitucional enquanto pauta organizacional da civilidade.

${ }^{60}$ HABERMAS, Jürgen.

A \& C R. de Dir. Administrativo e Constitucional, Belo Horizonte, ano 4, n. 15, p. 149-179, jan./mar. 2004 
A idéia neural de gestão pública compartida, pois, é alicerçada numa nova racionalidade gerencial, fundada nos direitos humanos e na noção de soberania popular, enquanto substância ética de uma determinada comunidade política, ao mesmo tempo em que remete para the rules of discourse and forms of argumentation that borrow their normative content from the validity basis of action oriented to reaching understanding. ${ }^{61}$ Tais regras do discurso e formas de argumentação foram apresentadas por nós como indispensáveis no processo de articulação tensa e conflituosa do agir administrativo.Desta forma, a teoria da discussão habermasiana nos é muito rica porque pressupõe uma rede de processos comunicativos, tanto dentro como fora dos espaços institucionais e dos seus corpos deliberativos, que sustenta a existência de palcos dialogicamente discursivos em que ocorre a formação da vontade e da opinião democráticas.

O que se sabe, por fim, é que a mudança do paradigma administrativo estatal depende exatamente da confluência de iniciativas do próprio Estado com ações políticas dos atores sociais que são alcançados pela administração, necessitando serem gerados instrumentos e mecanismos viabilizadores desta mutação.

\section{Bibliografia}

AGERE, Saul. Promoting Good Governance: principles, practices and perspectives. London: Martheson, 2002.

ARAGÃO, Lucia Maria de Carvalho. Razão Comunicativa e Teoria Social Crítica em Jürgen Habermas. Rio de Janeiro: Tempo Brasileiro, 1992.

AVRITZER, Leonardo. Cultura Política, Atores Sociais e Democratização: uma crítica às teorias da transição para a democracia. Revista Brasileira de Ciências Sociais, São Paulo, ano 10, n. 28,1995 .

AVRITZER, Leonardo. Sociedade Civil: Além da Dicotomia Estado-Mercado. In:

AVRITZER, Leonardo (Org.). Sociedade Civil e Democratização. Belo Horizonte: Del Rey, 1994.

BARRETO, Plínio. A Cultura Jurídica no Brasil (1822/1922). Rio de Janeiro: Imprensa Nacional, 1938.

BASTOS, Aureliano Cândido Tavares. A Província: estudo sobre a descentralização no Brasil. Brasília: Nacional, 1970.

BETANCOR, August. Las Administraciones Independientes: um reto para el Estado social y democratico del Derecho. Madrid: Siglo Veinteuno, 2002.

\section{${ }^{61}$ Op. cit}

A \& C R. de Dir. Administrativo e Constitucional, Belo Horizonte, ano 4, n. 15, p. 149-179, jan./mar. 2004 
BOHMAN, James. Public Deliberation: Pluralism, Complexity and Democracy. Boston: Madinson, 2002.

CASTELS, Manuel. La Sociedad de Redes. Madrid: Paidós, 2001.

COOKE, Maeve. Language and Reason: a study of Haberma's pragmatics. Cambridge: MIT, 2000.

COX, Raymund. Economic Globalization and the Limits to Liberal Democracy. In: McGREW, Antony (Ed.). The Transformation of Democracy? New York: Polity Press, 1997.

ENTERRÍA, Eduardo García de. Democracia, Jueces y Control de la Administración. Madrid: Civitas, 2001.

FAORO, Raymundo. Os Donos do Poder. Rio de Janeiro: Globo, 1984.

FILHO, Alberto Venâncio.Das Arcadas ao Bacharelismo. São Paulo: Perspectiva,1982.

FREITAS, Juarez. A Interpretação Sistemática do Direito. São Paulo: Malheiros, 1995.

FRIEDRICH, Carl J. Authority, Reason and Discretion. New York: Harvard University Press, 1998.

GORDILLO, Augustín.Tratado de Derecho Administrativo. Buenos Aires: Fundación de Derecho Administrativo, 1998.

GÜNTHER, Klaus. The Sense of Appropriateness: aplication discourses in morality and law. New York: State University of New York, 1999.

HABERMAS, Jürgen. A Constelação Pós-Nacional. São Paulo: Littera Mundi, 2001.

HABERMAS, Jürgen. La Soberanía Popular como Procedimiento: un concepto normativo de lo publico. In:Jürgen Habermas: moralidad, ética y política. Madrid: Alianza Editorial, 1993.

HABERMAS, Jürgen. Mudança Estrutural da Esfera Pública. Rio de Janeiro: Civilização Brasileira, 1988.

HABERMAS, Jürgen. Nos Limites do Estado. Folha de S.Paulo, jul. 1999.Caderno MAIS!, p. 5-4.

HABERMAS, Jürgen. On the pragmatics of social interaction. Cambridge: MIT, 2002.

HABERMAS, Jürgen. Strukturwandel der Öffentlichkeit. Boon: Darmstadt, 1978.

HABERMAS, Jürgen. Teoria de la Acción Comunicativa. Madrid: Paidós, 2000.

HELD, David. Democracy and the Global Order. New York: Polity Press, 1995.

HUSSERL, Edmund. A Crise das Ciências Européias. Brasília: UnB, 1989.

IGLÉSIAS, Francisco. Trajetória Política do Brasil. São Paulo: Cia. das Letras, 1993.

LEAL, Hamilton. História das Instituições Políticas do Brasil. Brasília: Ministério da Justiça, 1994.

LEAL, Rogério Gesta. Hermenêutica e Direito: considerações sobre a Teoria do Direito e os Operadores Jurídicos. 2. ed. Santa Cruz do Sul: Edunisc, 1999.

LEAL, Rogério Gesta. Teoria do Estado: cidadania e poder político na modernidade. 2. ed. Porto Alegre: Liv.do Advogado, 2001.

A \& C R. de Dir. Administrativo e Constitucional, Belo Horizonte, ano 4, n. 15, p. 149-179, jan./mar. 2004 
LOCKE, John. The Second Tratiese of Civil Governament. Berckley: U.P.Berckley, 1980.

LYRA, Augusto Tavares. Organização Política e Administrativa do Brasil. Rio de Janeiro: Olympio, 1954.

MARTINS, José de Souza. O Senso Comum e a Vida Cotidiana. Revista Sociologia, São Paulo, 1998

MOREIRA NETO, Diogo de Figueiredo.Curso de Direito Administrativo. Rio de Janeiro: Forense, 1996.

OFFE, Clauss. Demokratie und Wohlfahrtsstaat: Eine Europaeische Regimeform Unter dem Stress der Europaeischen Integration. Frankfurt: Streek, 1998.

PRADO JR., Caio. História do Desenvolvimento Econômico do Brasil. Rio de Janeiro: Círculo do Livro, 1996.

SANTOS, Milton. Metamorfoses do Espaço Habitável. São Paulo: HUCITEC, 1997.

SCHONBERGER, Roland Jordan. Legitimate Expectations in Administrative Law. Oxford: Oxford Press, 2000.

SOUSA, António Francisco de. Fundamentos Históricos de Direito Administrativo. Lisboa: Editores Associados, 1925.

VIANNA, Luiz Werneck (Org.). A Democracia e os Três Poderes no Brasil. Belo Horizonte: UFMG, 2002.

WEBER, Max. Sociologia do Direito. São Paulo: Civilização Brasileira, 1998. v. 1.

XESTA, Fernando; VAZQUEZ, Ernesto. La Orden Civil de la Republica. Ciudadania y distincion en el Estado igualitario. Madrid: Civitas, 2001.

YOUNG, Martin. Inclusion and Democracy. Oxford: Masters, 2002.

ZALUAR, Alba. Exclusão e Políticas Públicas: dilemas teóricos e alternativas políticas. Revista Brasileira de Ciências Sociais, São Paulo, v.12, n. 35, out.1997. 